\title{
FUNGSI ZUHUD TERHADAP KETENANGAN JIWA (Studi Analisis terhadap Tafsir Jailani Karya Abd al-Qadir Jailāni)
}

Tika Saripah, Yayan Mulyana dan Undang A. Kamaludin

Fakultas Ushuluddin UIN Sunan Gunung Djati Bandung

Jl.A.H.Nasution 105 Cibiru Bandung 40614, Indonesia

E-Mail : syarhyfah94@gmail.com

\begin{abstract}
The majority of people argue that calmness only exists in wealth and position so as to make it always pursues the luxury of life. On the other hand there are still many people who are confined suffering due to the inability to overcome the hardships of life due to poverty, failure and many other difficulties, ultimately many humans experience mental shock because of stress (stress) by a condition because it does not fulfill the desire. So Islam offers a solution of life zuhud as one method of mental calming. The purpose of this study is to find a correlation between zuhud with peace of mind tersebut.Adapun basis of this study that is, the verses of the Qur'an are reviewed by Tafsir Jailani by Sheikh Abdul Qadir Jailani.In this study the authors use the method of content analysis. In research tafsirnya using mawdhui'i method, namely research based on a particular theme. Based on the results of research that has been done by the author that Abdul Qadir Jailani The results of the study found that in some verses about zuhud there is categorization The world categorization in 3 verses (2). The nature and nature of the world 9 verses (3). The loss of choosing the world 9 verses. The interpretation reveals that zuhud is a life behavior that dislikes the life of the world and puts it first Hereafter, this is because knowledge and understanding of the nature d unia. So that they always run the righteous deeds that bring the servant to Allah, then Allah grant him the high dignity, the reward and the peace of the soul and kept away from the torment. When troubled, his heart will not be shaken, for he is always blessed for his destiny. Therefore, people who zuhud will always calm his soul
\end{abstract}

Keywords:

Zuhud; hereafter; peace of mind; Sheikh Abdul Qadir Jailani.

\begin{abstract}
Abstrak
Mayoritas orang berpendapat bahwa ketenangan hati hanya terdapat pada kekayaan dan jabatan sehingga membuatnya selalu memburu kemewahan hidup. Di sisi lain masih banyak manusia yang terkungkung penderitaan akibat ketidakmampuan mengatasi kesulitan hidup karena kemiskinan, kegagalan dan berbagai kesulitan lainnya, akhirnya banyak manusia mengalami kegoncangan jiwa karena tertekan (stress) oleh suatu kondisi karena tidak terpenuhinya keinginan tersebut. Maka Islam menawarkan solusi hidup zuhud sebagai salah satu metode penenangan jiwa.Tujuan penelitian ini adalah untuk mencari korelasi antara zuhud dengan ketenangan jiwa tersebut.Adapun dasar penelitian ini yaitu, ayat-ayat Alquranyang dikaji berdasarkan Tafsir Jailani karya Abd alQadir Jailāni.Dalam penelitian ini penulis menggunakan metode content analysis.Dalam penelitian tafsirnya menggunakan metode maudú $i$, yaitu penelitan berdasarkan tema tertentu. Berdasarkan hasil penelitian yang telah dilakukan oleh penulis bahwa Abd al-Qadir Jailāni. Hasil dari penelitian menemukan bahwa dalam beberapa ayat tentang zuhud terdapat kategorisasi tersendiri, adapun kategorisasi tersebut yakni (1).Permisalan dunia pada 3 ayat (2).Sifat dan hakikat dunia 9 ayat (3).Kerugian memilih dunia 9 ayat. Penafsir mengungkapkan bahwa zuhud merupakan prilaku hidup yang yang tidak menyukai kehidupan dunia dan mengutamakan akhirat, hal ini dikarenakan pengetahuan dan pemahamannya terhadap hakikat dunia. Sehingga mereka senantiasa menjalankan amal saleh yang mendekatkan hamba kepada Allah, maka Allah menganugerahkannya martabat tinggi, pahala dan ketenangan jiwa serta dijauhkan dari siksa, ketika susah, hatinya tidak akan terguncang, sebab ia senantiasa rido akan takdirnya. Oleh karena itu, orang yang zuhud akan senantiasa tenang jiwanya.
\end{abstract}

Kata Kunci:

Zuhud; akhirat; ketenangan hati; Abd al-Qadir Jailäni.

A. PENDAHULUAN

Manusia sebagai dianugrahi

Allah makhluk perasaan, kehidupannya

selalu

mendambakan kebahagiaan dan ketenagan hati. Seiring berkembangnya zaman, maka merajalela juga faham materialisme barat. Faham ini yang 
Tika Saripah, Yayan Mulyana dan Undang A. Kamaludin

menganggap bahwa kebahagiaan dan ketenangan hati hanya terdapat pada hal yang bersifat materi belaka yang berupa kesenangan harta, jabatan dan berbagai kemewahan dunia lainnya, sehingga menuntut manusia untuk hidup dengan gaya hedonisme.

Namun tidak semua lapisan masyarakat mampu memenuhi kebutuhan tersebut, sehingga ketika kemiskinan, kegagalan dan keterpurukan melanda, mereka akan mengalami kegoncangan jiwa karena tertekan atau stress oleh keadaan tersebut hingga menimbulkan berbagai kekacauan seperti kriminalitas pencurian, tindakan bunuh diri, dll.

Selain itu, beberapa hasil penelitian membuktikan bahwa orang miskin merasa kurang bahagia dan bahkan rentan terhadap gangguan mental yang serius, seperti depresi, skizofrenia, dan gangguan kepribadian. Di Indonesia, banyak terdapat kasus gila, bunuh diri, atau kriminalitas akibat dari stress yang mereka alami karena kemiskinan. Organisasi Kesehatan Dunia (WHO) menyimpulkan bahwa gangguan kesehatan mental memang dapat terjadi pada semua orang, namun resikonya jauh lebih rentan terjadi pada orang miskin, tuna wisma, pengangguran, dan orangorang berpendidikan rendah.

Kebanyakan masyarakat mendatangi psikiater untuk mengatasi stress tersebut. Namun itu semua tidaklah mengena, karena pengobatan modern hanya menyentuh bagian luarnya saja sedang aspek dalamnya tidak. Ini senada dengan yang dikatakan al-Sharqāwi bahwa metode penyembuhan penyakit jiwa seperti yang dilakukan oleh Ilmu Jiwa modern tidaklah mengarahkan penderita untuk menuju kepada Allah dan tidak juga diarahkan untuk meningkatkan dan mengembangkan upaya penyucian ruh iman dalam hatinya. ${ }^{2}$ Maka dari itu Alquran sebagai pedoman hidup senantiasa

${ }^{1}$ Dinar Gusti Hanani, Muhammad Syafiq, Jurnal Penelitian Psikologi "Mengatasi Ancaman Identitas Kemiskinan: Studi Kasus Sebuah Keluarga Miskin Di Surabaya”, 2013, Vol. 04, No. 02, 120-141.

2 Amir an Najar, "Ilmu Jiwa dalam Tasawuf Studi komparatif dengan Ilmu Jiwa Kontemporer", (Jakarta: Pustaka Azzam,2001), 221-222.
Fungsi Zuhud Terhadap Ketenangan Jiwa (Studi Analisis terhadap Tafsir Jailani Karya Abd alQadir Jailāni)

mampu menjawab berbagai persoalan yang muncul, adapun salah satu solusi yang ditawarkan ialah dengan hidup zuhud. Untuk mengatai hal tersebut penulis akan mengemukakan sebuah penafsiran yang dilakukan oleh salah satu mufasir yang berasal dari kalangan sufi yakni Abd Al-Qadir Jailānimengenai "Fungsi Zuhud terhadap Ketenangan Jiwa".

\section{B. HASIL DAN PEMBAHASAN}

1. Penafsiran Kata "Zuhud" dalam Tafsir Jailani

Kata Zuhud ditemukanhanya ada satu kali dalam Alquran, yakni QS.Yūsuf ayat 20. Namun secara maknawi indikasi mukmin untuk berzuhud tersirat pada berbagai ayat. Dalam surat Yūsuf disebutkan dalam kisah Nabi Yusuf yang dilemparkan ke dalam sumur oleh saudara-saudaranya lalu meninggalkannya sendirian. Muhammad bin Ishaq mengatakan bahwa setelah Yusuf ditinggalkan di dalam sumur, kemudian Allah menggerakkan sekelompok musafir menghampirinya dan mereka berhenti dekat sumur, lalu sebagian dari mereka mengutus seseorang untuk mengambil air. Setelah dia datang ke sumur dan menurunkan timba, Yusuf bergantung pada timba tersebut.Lalu para musafir itu mengangkat Yusuf ke atas dan di bawanya untuk dijadikan budak lalu dijual dengan harga yang murah. ${ }^{3}$ Sesuai firman Allah QS. Yūsuf [12]: 20;

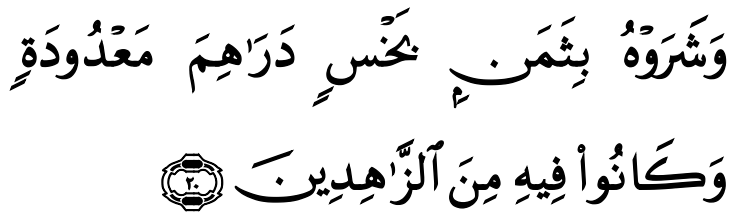

"Dan mereka menjual Yusuf dengan harga yang murah, yaitu beberapa dirham saja, dan mereka merasa tidak tertarik hatinya kepada Yusuf "

Mereka menjual Yusuf dengan harga yang murah karena mereka tidak menyukainya sehingga berpaling darinya. Para musafir tersebut disifatkan zuhud dalam hal ini, karena

${ }^{3}$ Abd al-Qadir Jailāni, Tafsīir al-Jailāni, Pakistan: Maktabah Ma'rufiyyah, Jilid.2,344. 
Tika Saripah, Yayan Mulyana dan Undang A. Kamaludin

mereka meninggalkannya dengan menjualnya bahkan dengan harga yang rendah karena saking tidak menyukai Yusuf, maka harga rendah itu pun disetujuinya yang penting tidak ada Yusuf diantara mereka. Mereka menjual Yusuf dengan harga yang murah, hanya dengan beberapa dirham saja. Dalam riwayat Ibn 'Abbas hanya 22 dirham, riwayat Ikrimah 40 dirham dalam suatu riwayat hanya 20 dirham.Namun dalam tafsir lain ada yang berpendapat bahwa yang menjual Yusuf itu adalah saudara-saudaranya, mereka demikian karena menginginkan perhatian ayah mereka agar perhatian tersebut tertuju padanya bukan pada Yusuf, karena perhatian tersebut berharga bagi mereka.

2. Kategorisasi dan Deskripsi Ayat - Ayat tentang Zuhud serta Penafsirannya dalam Tafsir Jailani

Terdapat ayat - ayat yang di dalamnya tersirat makna kezuhudan. Namun penulis mengkategorisasikannya ke dalam beberapa bagian, yakni :

1. Permisalan dunia

Berikut ayat dan penafsirannya :

1) .QS. Yūnus [10]: 24 :
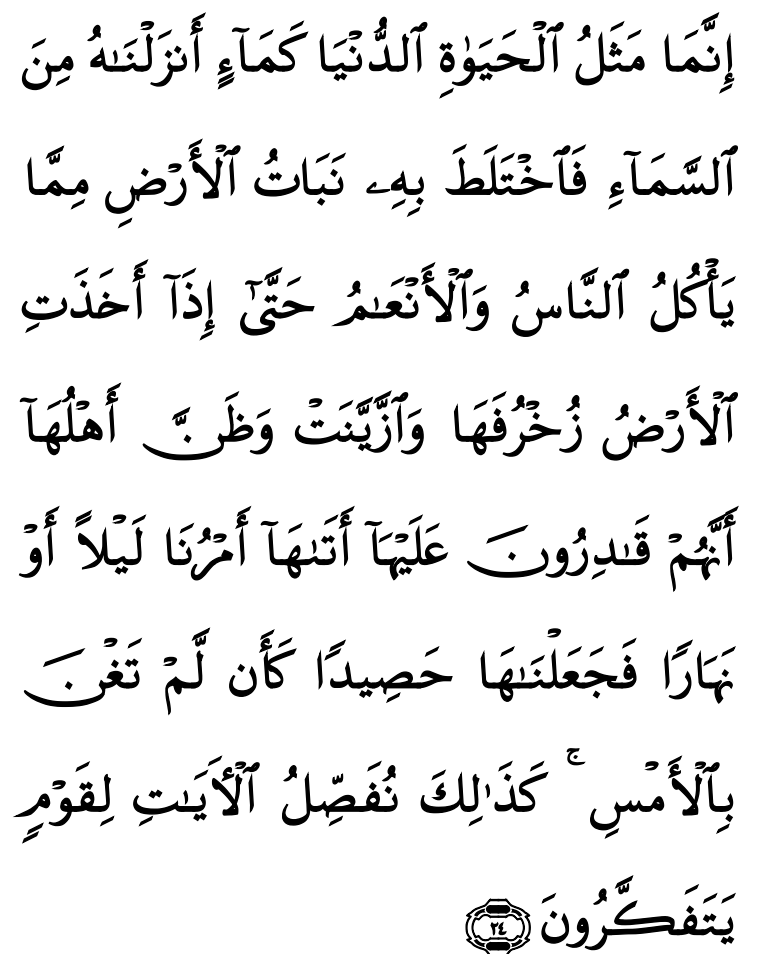

Fungsi Zuhud Terhadap Ketenangan Jiwa

(Studi Analisis terhadap Tafsir Jailani Karya Abd al-

Qadir Jailāni)

"Sesungguhnya

perumpamaan

kehidupan duniawi itu, adalah seperti air yang Kami turunkan dan langit, lalu tumbuhlah dengan suburnya karena air itu tanam-tanaman bumi, di antaranya ada yang dimakan manusia dan binatang ternak. Hingga apabila bumi itu telah sempurna keindahannya, dan memakai perhiasannya, dan pemilik-permliknya mengira bahwa mereka pasti menguasasinya , tiba-tiba datanglah kepadanya azab Kami di waktu malam atau siang, lalu Kami jadikan laksana tanam-tanaman yang sudah disabit, seakan-akan belum pernah tumbuh kemarin. Demikianlah Kami menjelaskan tanda-tanda kekuasaan kepada orangorang berfikir."

2) . QS. Al Kahfi[18]: 45-46

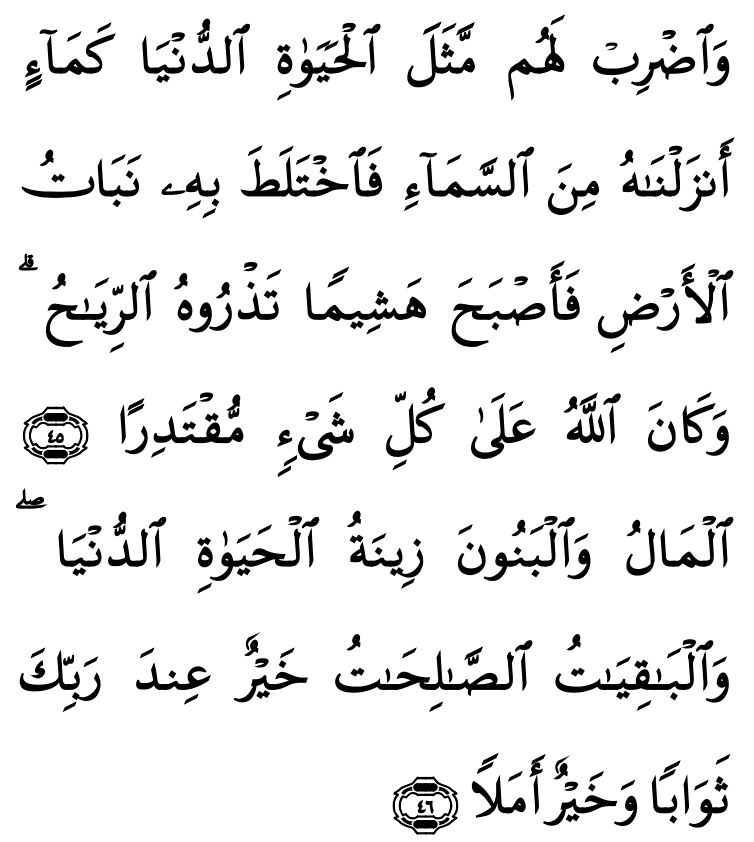

"Dan berilah perumpamaan kepada mereka, kehidupan dunia sebagai air hujan yang Kami turunkan dari langit, maka menjadi subur karenanya tumbuhtumbuhan di muka bumi, kemudian tumbuh-tumbuhan itu menjadi kering yang diterbangkan oleh angin. Dan adalah Allah, Maha Kuasa atas segala sesuatu. Harta dan anak-anak adalah perhiasan kehidupan dunia tetapi 
Tika Saripah, Yayan Mulyana dan Undang A. Kamaludin

amalan-amalan yang kekal lagi saleh adalah lebih baik pahalanya di sisi Tuhanmu serta lebih baik untuk menjadi harapan"

Pada kedua ayat tersebut terdapat persamaan dalam penafsiran. Yakni keduanya menceritakan tentang perumpamaan dunia yang diibaratkan sebagai air yang turun dari langit, dimana air itu memiliki tingkah yang ajaib dan menipu. Dimana awalnya air tersebut menumbuhkan tanaman - tanaman dengan subur dan menjadi makanan bagi manusia dan binatang ternak namun kemudian air itu menghancurkan tanaman tersebut dalam waktu sekejap, sehingga pemiliknya merasa kehilangan. Karena pada awalnya orang-orang tersebut merasa bahwa tanaman itu miliknya dan berada dalam kekuasaannya, padahal semuanya hanya sementara dan merupakan milik sang pencipta. Begitu pula kehidupan dunia, dunia yang kita singgahi hanyalah sementara, anak, keluarga dan harta yag kita miliki, semuanya berada dalam kekuasaan Allah. Namun di sisi lain kedua ayat ini memiliki perbedaan tersendiri, dalam QS. Yūnus [10]: 24 merupakan peringatan bagi orang kaya yang sombong dan membanggakan diri dengan kelebihannya, padahal semua yang dimilikiya di dunia hanyalah fatamorgana yang menipunya, maka tersesatlah ia dan jauh dari petunjuk bagi orang yang sombong karena tertipu oleh fatamorgana tersebut. ${ }^{4}$

Sedangkan dalam QS. Al Kahfi[18]: 4546 menceritakan tentang peringatan bagi penduduk dunia yang berharta dan merasa nyaman dan takjub dengan keindahan dunia tersebut. Padahal Kehidupan dunia akan menuntut pecintanya agar senantiasa mengikutinya hingga melakukan berbagai kemaksiatan dan menyebabkan murkanya Allah. ${ }^{5}$ Namun orang - orang yang pandai dalam meneliti dan memahami kehidupan ini semakin mengetahui bahwa dunia ini tidaklah kekal, sehingga sangtlah hina mengagungkan

\footnotetext{
${ }^{4}$ Abd al-Qadir Jailāni, Tafsìr al-Jailāni Jilid.2 ,260

5 Abd al-Qadir Jailāni, Tafsìir al-Jailāni Jilid.3
}

Fungsi Zuhud Terhadap Ketenangan Jiwa (Studi Analisis terhadap Tafsir Jailani Karya Abd alQadir Jailāni)

hal yang rendah seperti harta, anak dan kedudukan, karena semua perhiasan dunia hanyalah sementara dan kepalsuan belaka. Maka dari itu mereka akan memilih mengutamakan kehidupan akhirat yang kekal. Yakni mereka senantiasa menjalankan amalamal saleh yang dapat mendekatkan hamba kepada Allah sehingga meraih martabat tinggi dan selamat dari siksa, selain itu pahala yang besar pun menantinya dan mereka mendapatkan kelezatan ruhani berupa ketenangan jiwa. ${ }^{6}$

Orang yang pandai dalam memahami permisalan dunia ini akan cerdas dalam melangkah dan menentukan pilihan. Tak ada keraguan baginya untuk berpaling dari dunia dan senantiasa mengutamakan akhirat. Syekh Abd Al-Qadir Jailāni menganalogikan dunia dengan sesuatu yang menjijikan. beliau mengatakan agar seseorang mudah dalam berzuhud maka pandanglah dunia ini dengan hina sebagai mana engkau memandang orang yang sedang buang hajat di dalam WC. ${ }^{7}$ Bila ini dilakukan pasti kita merasa jijik terhadapnya.

Dikatakan dalam hadits yang artinya "Rasul memberikan gambaran tentang nilai dunia di sisi Allah "Demi Allah, dunia dibandingkan dengan akhirat hanyalah seperti salah seorang diantara kalian yang mencelupkan jarinya ini ke lautan, lihatlah apa yang dapat diambil oleh jarinya itu" ${ }^{\prime 8}$ karena saking tidak ada apa-apanya dunia itu dibandingkan akhirat. Maka dari itu akhirat lebih baik dan lebih pantas untuk dijadikan sebagai harapan.

\section{Sifat dan hakikat dunia dalam Alquran}

Adapun sifat dan hakikat dunia itu antara lain :

1) .Kehidupan yang sementara dan kesenangan yang menipu

a) .QS. 'Alì 'Imrān [03]: 185

${ }^{6}$ Abd al-Qadir Jailāni, Tafsìr al-Jailāni Jilid.3 ,77-78.

${ }^{7}$ Abd al-Qadir Jailāni, Raihlah Hakikat Jangan Abaikan Syari'at, (terjemahan Adab al Suluk wa al Tawasul ila Manazil al Muluk) Pustaka Hidayah, Bandung, 2013, cet.V, ,60.

${ }^{8}$ HR. Muslim (7376) dari Mustaurid. 
Tika Saripah, Yayan Mulyana dan Undang A.
Fungsi Zuhud Terhadap Ketenangan Jiwa

(Studi Analisis terhadap Tafsir Jailani Karya Abd al-

Qadir Jailāni)

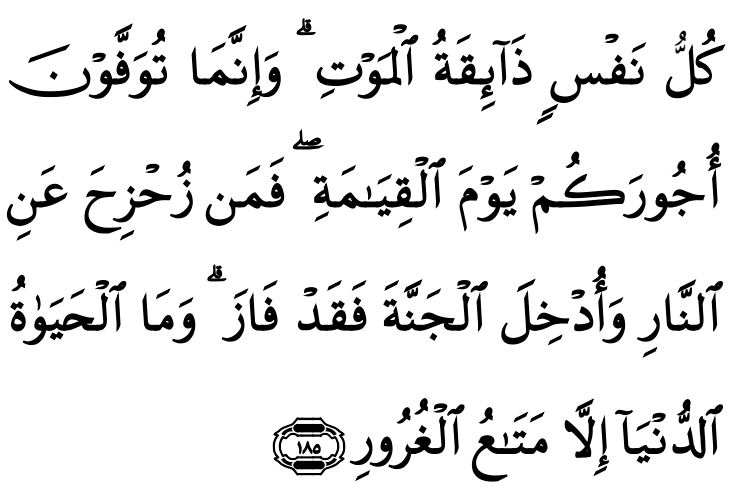

"Tiap-tiap yang berjiwa akan merasakan mati. Dan sesungguhnya pada hari kiamat sajalah disempurnakan pahalamu. Barangsiapa dijauhkan dari neraka dan dimasukkan ke dalam syurga, maka sungguh ia telah beruntung. Kehidupan dunia itu tidak lain hanyalah kesenangan yang memperdayakan."

b) .QS. Al-A'rāf [07]: 51

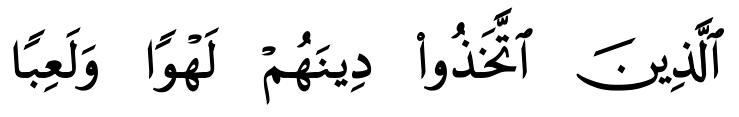

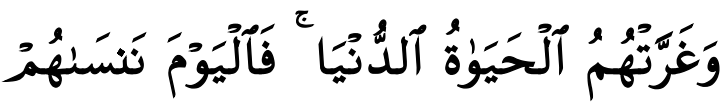
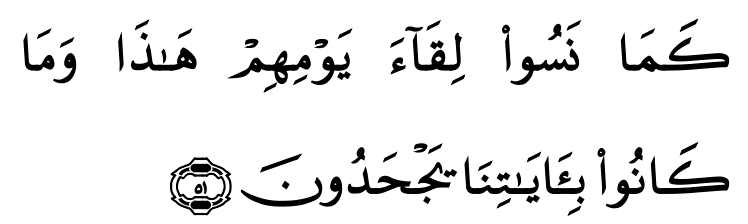

"(yaitu) orang-orang yang menjadikan agama mereka sebagai main-main dan senda gurau, dan kehidupan dunia telah menipu mereka." Maka pada hari (kiamat) ini, Kami melupakan mereka sebagaimana mereka melupakan pertemuan mereka dengan hari ini, dan (sebagaimana) mereka selalu mengingkari ayat-ayat Kami."

c) .QS. Al- Ra'd [13]:26

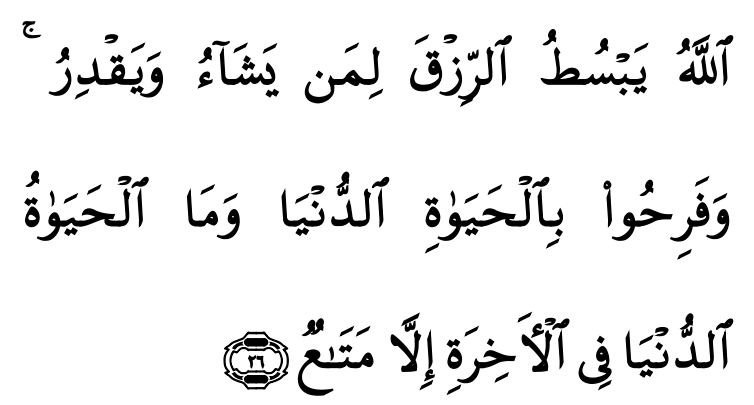

"Allah meluaskan rezki dan menyempitkannya bagi siapa yang Dia kehendaki. Mereka bergembira dengan kehidupan di dunia, padahal kehidupan dunia itu kehidupan akhirat, hanyalah kesenangan. Orang-orang kafir berkata: "Mengapa tidak diturunkan kepadanya tanda dari Tuhannya?" Katakanlah: "Sesungguhnya Allah menyesatkan siapa yang Dia kehendaki dan menunjuki orang-orang yang bertaubat kepadaNya", orang-orang yang beriman dan hati mereka manjadi tenteram dengan mengingat Allah. Ingatlah, hanya dengan mengingati Allah-lah hati menjadi tenteram"

d) .QS. Luqmān [31] : 33

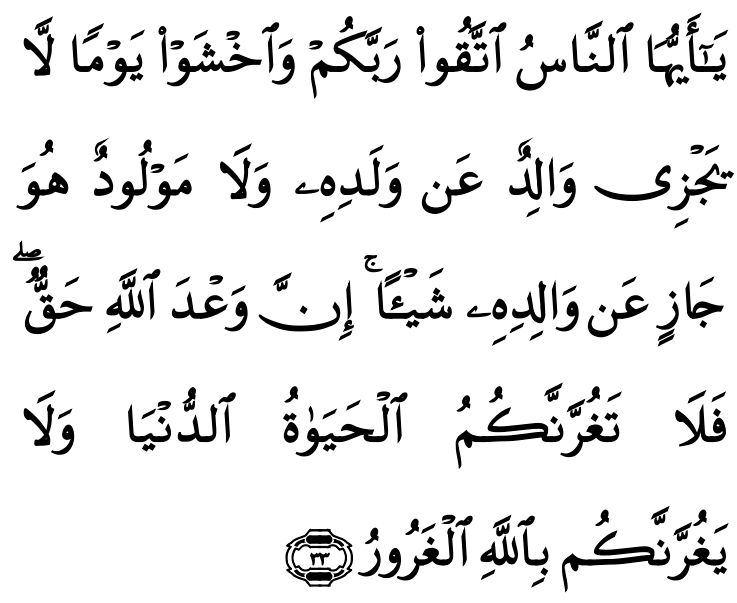

"Hai manusia, bertakwalah kepada Tuhanmu dan takutilah suatu hari yang seorang bapak tidak dapat menolong anaknya dan seorang anak tidak dapat menolong bapaknya sedikitpun. Sesungguhnya janji Allah adalah benar, 
Tika Saripah, Yayan Mulyana dan Undang A. Kamaludin

maka janganlah sekali-kali kehidupan dunia memperdayakan kamu, dan jangan penipu memperdayakan kamu dalam (menaati) Allah"

Berdasarkan penafsiran Abd al-Qadir Jailāni, penulis menyimpulkan bahwa ayat ayat tersebut memiliki persamaan dalam mengungkapkan sifat dunia sebagai kesenangan yang menipu. Yakni semuanya menerangkan bahwa dunia itu hanyalah kehidupan yang sementara, bahwa semua yang berada dalam genggaman manusia itu ibarat pinjaman semata. Mereka yang terpedaya oleh harta, kedudukan dan berbagai kenikmatan lain. Dengan kenikmatannya dunia membuat manusia memujanya hingga melupakan kehidupan akhirat, mereka kira bahwa dunia itu kehidupan yang sebenarnya, padahal semuanya hanyalah kesenangan yang memperdaya agar mereka tertipu dalam kenikmatan yang tidak kekal.

Namun dalam penafsirannya ayat - ayat tersebut memiliki ke khasan tersendiri, yakni antara lain dalam QS. 'Ali 'Imrān [03]: 185, menerangkan bahwa setiap jiwa akan megalami kematian untuk kembali kepadaNya, dan suatu saat mereka akan menerima balasan dari setiap amal yang mereka kerjakan di dunia pada hari pembalasan di akhirat. Karenanya beramal solehlah ketika di dunia dan jangan sampai menjadi orang merugi di akhirat karena tertipu oleh kenikmatannya yang menipu karena dunia itu hanya kesenangan yang memperdayakan.

Dalam QS. Al-A'rāf [07]: 51, mufasir menjelaskan bahwa orang-orang yang menjadikan agama mereka sebagai main-main dan senda gurau, mereka bermain-main dalam dunia dan kenikmatannya yang tampak, mengumbar nafsunya serta membohongkan Rasul dan Kitab-Nya, mereka itu merupakan orang yang tertipu oleh kehidupan dunia, dan melupakan perjanjian yang mereka sepakati pada awal fitrah mereka, perjanjian tentang fitrah tauhid. Maka pada hari kiamat semuanya akan diperlihatkan. Allah akan melupakan mereka sebagaimana mereka melupakan penciptanya ketika di dunia, orang
Fungsi Zuhud Terhadap Ketenangan Jiwa (Studi Analisis terhadap Tafsir Jailani Karya Abd alQadir Jailāni)

yang dilupakan Allah pada hari yang sangat penting itu termasuk orang yang celaka. ${ }^{9}$

Adapun dalam QS. Al- Ra'd [13]:26-28, beliau menerangkan perihal penduduk mekkah yang membanggakan kekayaan dan derajatnya, dan menghina orang mukmin yang fakir miskin. Padahal semua itu hanyalah kehidupan dunia yang sifatnya sementara dan kenikmatannya akan rusak begitu pula kesenangannya sedikit serta menyengsarakan, dan Allah-lah yang Maha Berkehendak untuk meluaskan dan menyempikan rizki seseorang. ${ }^{10}$

Orang - orang kafir mempertanyakan tentang tanda dan bukti kepada Rasul tentang kebenaran pengutusannya untuk melindungi keimannya tersebut. Allah pun menjawab Katakanlah pada mereka Muhammad, tiada bagiku kecuali risalah. Allah merupakan sandaran bagi batin para hamba-Nya. Allah yang berkuasa untuk menyesatkan seseorang dan memberi petunjuk agar ia bertaubat. Orang-orang yang beriman dengan tauhid yang benar hati mereka akan tentram ketika berzikir mengingat Allah, menjadikan-Nya sebagai satu-satunya sandaran hati. Dengannya ia kan terhindar dari taklid yang batil dan mencapai derajat musyahadah serta dijauhkan dari kebingungan. ${ }^{11}$

Dan dalam QS. Luqmān [31] : 33 mufassir memaparkan peringatan Allah pada manusia agar bertakwa pada Allah, waspadalah terhadap siksaanya. Karena siksaan itu bagi hambanya yang banyak maksiat. Karena di akhirat setiap jiwa akan menanggung terhadap yang ia kerjakan di dunia, bapak dan anak tidak dapat saling menolong, mereka menanggung beban masing-masing dan menuntut apa yang Allah janjikan dalam Alquran, dan Allah tidak pernah mengingkari janjinya. Maka janganlah tertipu oleh kehidupan dunia yang

\footnotetext{
${ }^{9}$ Abd al-Qadir Jailāni, Tafsìir al-Jailāni, Jilid.1 , 329 .

10 Abd al-Qadir Jailāni, Tafsìr al-Jailāni Jilid.2 , 399.

11 Abd al-Qadir Jailāni, Tafsìr al-Jailāni, Jilid.2 ,399.
} 
Tika Saripah, Yayan Mulyana dan Undang A. Kamaludin

memperdaya dimana di dalamnya berisi tipuan setan agar manusia melakukan kemaksiatan. ${ }^{12}$

Keadaan dunia juga banyak dibicarakan dalam hadits, diantaranya seperti hadits yang diriwayatkan Abu Hurairah bahwa Rasulullah bersabda :

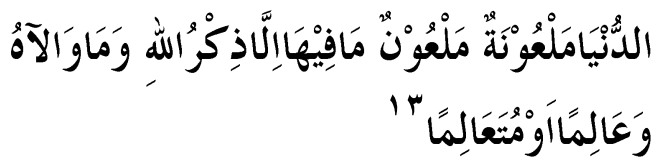

"Dunia itu terlaknat dan terlaknat pula apa yang ada di dalamnya kecuali dzikrullah, Amal ketaatan kepada Allah dan Seorang alim atau peuntut ilmu",14

Maksud dari sabda Nabi "Dunia itu terlaknat dan terlaknat pula apa yang ada di dalamnya" ialah dengan dijauhkan dari rahmat Allah , atau bermakna dunia dan apaapa yang ada di dalamnya akan menjauhkan seseorang dari Allah dan membuatya lalai dari Allah. Beliau juga bersabda "Kalaulah dunia ini di sisi Allah seharga sayap nyamuk, tentunya Dia tidak akan memberikan kepada orang kafir walaupun hanya seteguk air" ${ }^{\prime 15}$

Kemudian dalam suatu riwayat juga diceritakan "Pada suatu Hari Rasulullah melewati sebuah pasar, sedang para sahabat berada di sekeliling beliau.Beliau melewati bangkai anak kambing yang telinganya kecil. Beliau pun mendekatinya lalu menarik dengan menenteng telinganya beliau keudian bersabda "Adakah diatara kalian yang mau membeli (bangkai kambing) ini hanya dengan satu dirham?" Para sahabat menjwab "Berapa pun harganya, kami tidak mau membeli, untuk apa bakai ini?" beliau bersabda lagi "Lantas adakah diantara kalian yang mau mengambilnya secara cuma-cuma?" Sahabat

\footnotetext{
${ }^{12}$ Abd al-Qadir Jailāni, Tafsir Jailani, Jilid.4 , 51

- حدثنا علي بن ميمون الرقي. حدثنا أبو خليد، عتبة بن حماد 13 الدمشقي عن ابن ثوبان، عن عطاء بن قرة، عن عبد الله بن ضمرة السلولي.

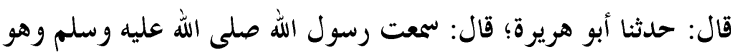
يقول

${ }^{14}$ Hadits riwayat at Tirmidzi (2322) dishahihkan oleh al Albani dalam silsilah shahihah (2797)

${ }^{15}$ HR.Hakim (7847) dan at Tirmidzi (2320) serta dishahihkan oleh al Albani dalam shahih al Jami' (5292)
}

Fungsi Zuhud Terhadap Ketenangan Jiwa (Studi Analisis terhadap Tafsir Jailani Karya Abd al-

Qadir Jailāni)

kemali menjawab "Demi Allah, meskipun ia hidup, tetap saja ia cacat, sebab telinganya kecil, lebih-lebih sudah jadi bangkai" Rasul pun bersabda "Demi Allah dunia ini lebih hina di mata Allah daripada (hinanya) bangkai kambing ini di mata kalian"16

Berarti disimpulkan sifat dunia itu selain kesenangan yang menipu ia juga sangat rendah dan tidak ada apa-apanyadibanding kehidupan akhirat.

\section{2).Permainan yang melalaikan}

a) .QS. Al-'Ankabūt [29]: 64

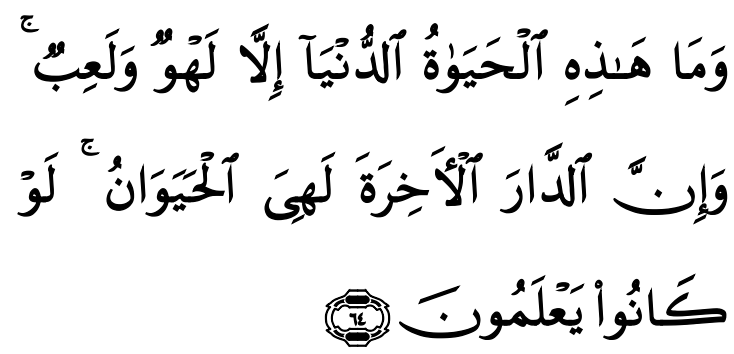

"Dan tiadalah kehidupan dunia ini melainkan senda gurau dan main-main. Dan sesungguhnya akhirat itulah yang sebenarnya kehidupan, kalau mereka mengetahui."

1. QS. Al-Hadid [57]: 20
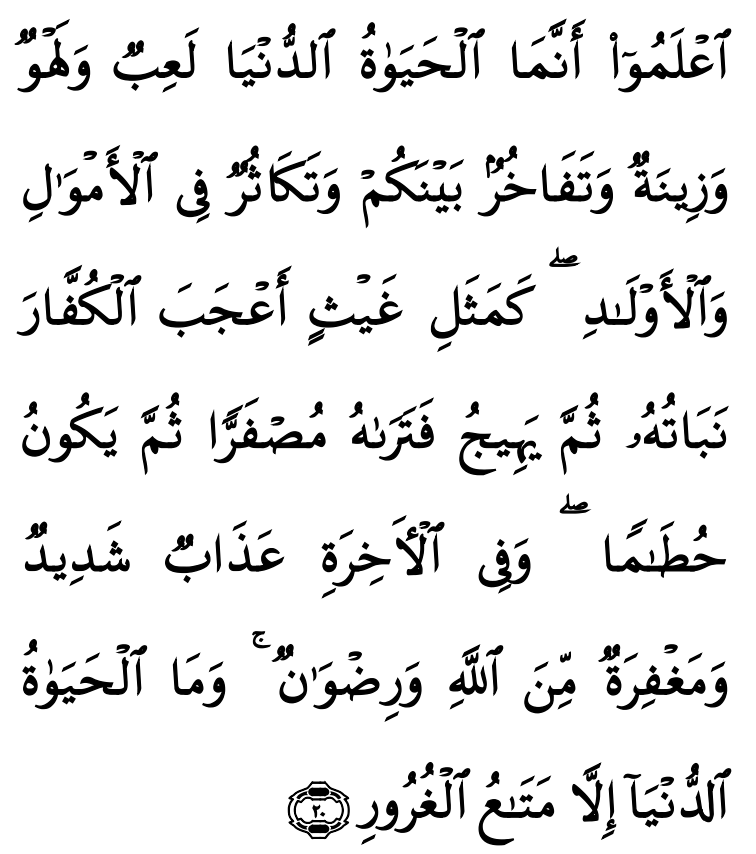
Tika Saripah, Yayan Mulyana dan Undang A. Kamaludin

"Ketahuilah, bahwa sesungguhnya kehidupan dunia ini hanyalah permainan dan suatu yang melalaikan, perhiasan dan bermegah-megah antara kamu serta berbangga-banggaan tentang banyaknya harta dan anak, seperti hujan yang tanam-tanamannya mengagumkan para petani; kemudian tanaman itu menjadi kering dan kamu lihat warnanya kuning kemudian menjadi hancur.Dan di akhirat (nanti) ada azab yang keras dan ampunan dari Allah serta keridhaan-Nya. Dan kehidupan dunia ini tidak lain hanyalah kesenangan yang menipu."

Kedua ayat diatas penulis klasifikasikan ke dalam sifat dan hakikat dunia yang merupakan permainan melalaikan dimana dalam QS. Al-'Ankabūt [29]: 64 mufassir menafsirkan bahwa dunia itu merupakan permainan melalaikan dimana perhiasan dan kenikmatannya fana dan tidak tetap perputaran yang ada padanya tidak hakiki semuanya hanyalah fatamorgana. Dan di akhirat itu memiliki kenikmata hakiki dan kelezatan ruhani yang tinggi. ${ }^{17}$ Perhiasan dunia itu hanyalah permainan yang dihiasi dengan kebatilan

Namun dalam QS.Al-Hadid [57]: 20 dijelaskan lebih lengkap dan kompleks, selain pemaparan yang serupa pada QS. Al-'Ankabūt [29]: 64 padanya juga terdapat penjelasan orang yang Mereka yang memepermainkan dunia dan bermain- main di dalamnya ialah orang yang lalai dan yang dihalangi dari rahmat Allah. Dunia itu akan menjengkelkan dan melalaikannya yakni menjauhkan mereka dari akhirat yang merupakan kehidupan yang abadi. mereka menetap pada perhiasan yang dihiasi setan yakni dengan memenuhi keinginan syahwat, memiliki pakaian yang indah, angan-angan tinggi tentang keduniaan dan syahwat binatang. ${ }^{18}$

Selain itu juga terdapat perumpamaan dunia sebagai air dari langit yang

${ }^{17}$ Abd al-Qadir Jailāni, Tafsìr al-Jailāni, Jilid.3 ,506.

18 Abd al-Qadir Jailāni, Tafsīr al-Jailāni Jilid.2 ,144-145.
Fungsi Zuhud Terhadap Ketenangan Jiwa

(Studi Analisis terhadap Tafsir Jailani Karya Abd alQadir Jailāni)

meumbuhkan tanaman yang subur hingga akhirnya menguning dan mengering kemudian menjadi hancur seperti jerami kering yang diterbangkan angin tanpa ada kemanfaatan padanya. Begitu pula dengan dunia yang menampakan keindahan namun lama kelamaan dunia pun pada akhirya akan menampakan kecacatannya, karena keindahannya tersebut tidaklah abadi. Kerugian ini akan muncul pertama kali pada orang lalai dan mereka tidak bisa mereka mengambil bagiannya di akhirat, mereka hanya mendapat balasan adzab yang keras karena menyibukkan diri terhadap dunia. Dan ada pula ampunan Allah yang akan menutupi dosa di hadapan manusia dan menghapuskannya. Sedang keridhaan-Nya akan mendidik hati hingga dapat melihat kebaikan dan kelemahan serta kedustaan pada dunia. Kehidupan dunia hanyalah kesenangan yang menipu bagi orang yang dapat mengambil pelajaran. Dan orang yang tertipu dengan dunia maka pantas baginya neraka wail dan kebinasaan serta haram baginya kesenangan. ${ }^{19}$

\section{3) Cobaan}

Adapun sifat dan hakikat dunia sebagai cobaan tercantum salah satunya dalam QS.AlTaghabūn [64]: 15

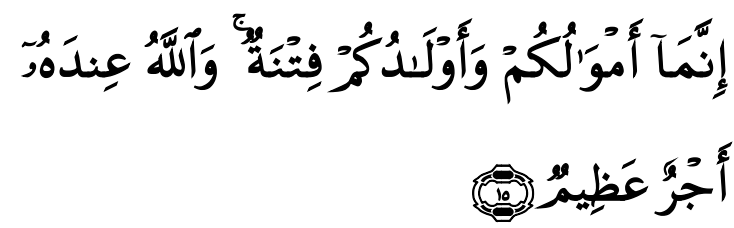

"Dan ketahuilah, bahwa hartamu dan anak-anakmu itu hanyalah sebagai cobaan dan sesungguhnya di sisi Allahlah pahala yang besar."

Mufasir menjelaskan bahwa kehidupan dunia yang berupa anak dan harta adalah cobaan yang besar. Karenanya, ketika seseorang berusaha dengan keras bagi mereka maka berhati-hatilah dan ingatlah bahwa keduanya merupakan perangkap setan, maka

19 Abd al-Qadir Jailāni, Tafsìr al-Jailāni,Jilid.2, ,144-145. 
Tika Saripah, Yayan Mulyana dan Undang A. Kamaludin

dari itu jangan sampai tertipu olehnya. Hendaknya berhati-hati ketika seseorang mulai mencintai anak dan harta tersebut sehingga seluruh waktu yang ada disibukkan hanya untuk kepentingan mereka hingga melupakan Allah. Maka orang yang seperti ini terlempar dari golongan orang - orang yang ikhlas, padahal orang yang ikhlas itu memiliki pahala yang besar. ${ }^{20}$

Oleh karena itu Rasul senantiasa memperingatkan umatnya agar berhati-hati terhadap fitnah dunia. Dalam hadis lain beliau bersabda "Sesungguhnya dunia itu manis dan hijau, Allah menjadikan kamu berkuasa di atasnya untuk melihat apa yag kalian lakukan. Karena itu, takutlah akan fitnah dunia dan fitnah wanita, karena fitnah yang pertama menimpa Bani Israil adalah fitnah wanita" ${ }^{, 2}$

4) Sengaja dijadikan indah untuk kesenangan

a) QS. Al-Baqarah [02]: 212
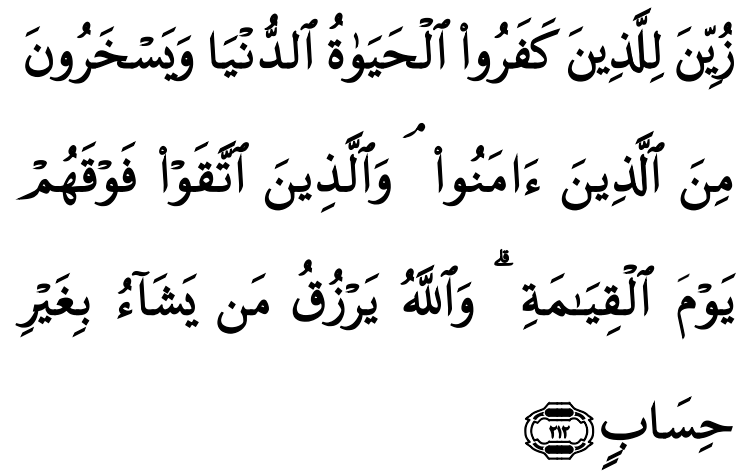

"Kehidupan dunia dijadikan indah dalam pandangan orang-orang kafir, dan mereka memandang hina orang-orang yang beriman. Padahal orang-orang yang bertakwa itu lebih mulia daripada mereka di hari kiamat. Dan Allah memberi rezki kepada orang-orang yang dikehendakiNya tanpa batas."

b) QS. 'Ali 'Imrān [03]: 14

${ }^{20}$ Abd al-Qadir Jailāni, Tafsīir al-Jailāni, Jilid.5 , 215-216.

${ }^{21}$ Hr.Muslim (7124).

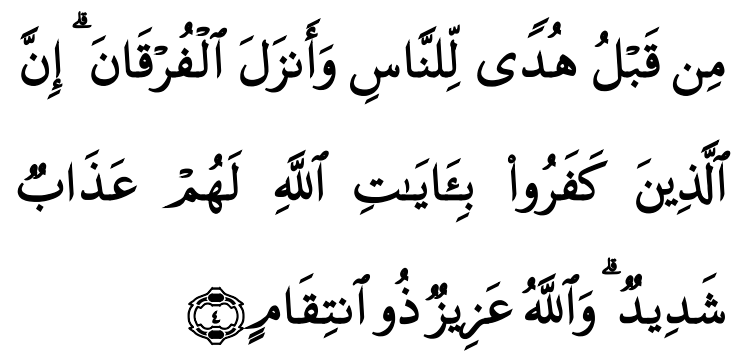

"Dijadikan indah pada (pandangan) manusia kecintaan kepada apa-apa yang diingini, yaitu: wanita-wanita, anak-anak, harta yang banyak dari jenis emas, perak, kuda pilihan, binatang-binatang ternak dan sawah ladang. Itulah kesenangan hidup di dunia, dan di sisi Allah-lah tempat kembali yang baik (surga)."

Kesamaan dari penafsiran pada dua ayat di atas ialah keduanya memberitahukan bahwa dunia yang samar itu sengaja dijadikan terlihat indah dalam pandangan manusia supaya menjadi kencintaan dalam hatinya. Mereka menyombongkan diri dengan harta, keturunan dan jabatan yang mereka miliki.

Adapun perbedaan dari keduanya yakni pada ayat QS. Al-Baqarah [02]: 212 menceritakan tentang kesombongan orang kafir terhadap orang mukmin yang fakir karena harta yang mereka miliki dan mereka banggakan, sehingga mereka menghina kefakiran orang mukmin tersebut. Padahal di hari kiamat orang mukmin yang bertakwa tersebut lebih mulia darinya, karena di dunia ini Allah Maha Berkehendak untuk memberi rizki pada seseorang bukan karena hina atau mulianya orang tersebut di dunia. ${ }^{22}$

Sedangkan QS. 'ATi 'Imrān [03]: 14 menjelaskan tentang gambaran manusia yang memiliki harta dari jenis emas, perak, binatang ternak unta, sapi, domba, sawah dan ladang dan keturunan yang baik, lalu mereka merasa bangga dengan hal tersebut, sehingga mereka mencintainya dan saling bersaing untuk saling menyombongkan dan menampakannya. Padahal semuanya hanya

${ }^{22}$ Abd al-Qadir Jailāni, Tafsìir al-Jailāni, Jilid.1 ,202-203. 
Tika Saripah, Yayan Mulyana dan Undang A. Kamaludin

kesenangan hidup yang akan rusak dan dapat mencegah manusia untuk sampai ke surge ma'wa dimana di dalamnya terdapat kenikmatan yang kekal. ${ }^{23}$

\section{5) Kerugian memilih dunia}

Seseorang yang memilih dunia daripada akhirat juga mendapat berbagai kerugian yang besar. Adapun ayat-ayat yang menerangkannya yaitu :

a) QS. Al-A'rāf [07] : 176
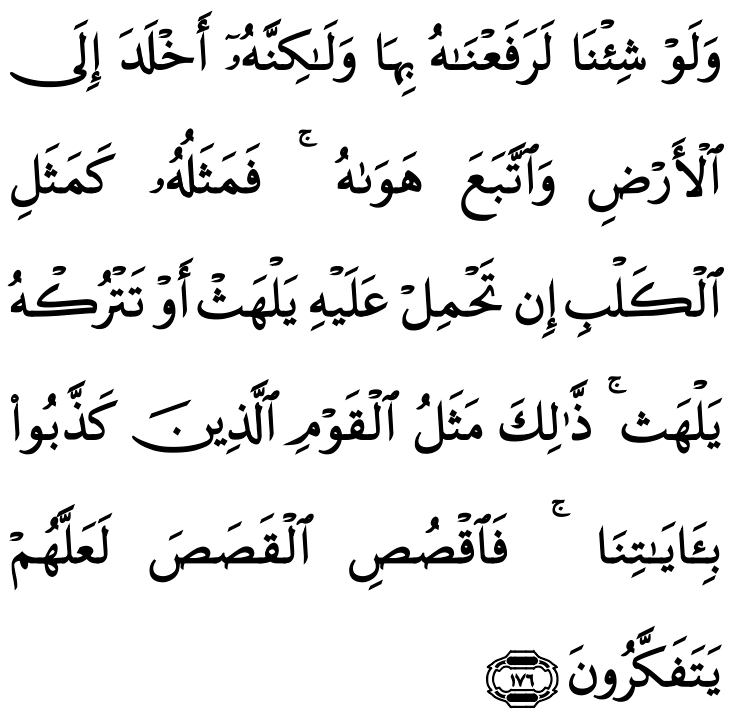

"Dan kalau Kami menghendaki, sesungguhnya Kami tinggikan nya dengan ayat-ayat itu, tetapi dia cenderung kepada dunia dan menurutkan hawa nafsunya yang rendah, maka perumpamaannya seperti anjing jika kamu menghalaunya diulurkannya lidahnya dan jika kamu membiarkannya dia mengulurkan lidahnya . Demikian itulah perumpamaan orang-orang yang mendustakan ayat-ayat Kami. Maka ceritakanlah kisah-kisah itu agar mereka berfikir."

b) QS. Hūd [11]: 15-16

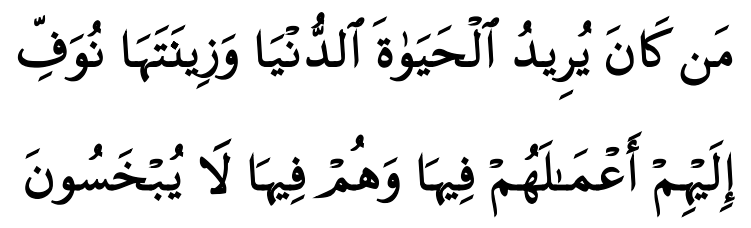

${ }^{23}$ Abd al-Qadir Jailāni, Tafsìir al-Jailāni, Jilid.1 ,260-261.

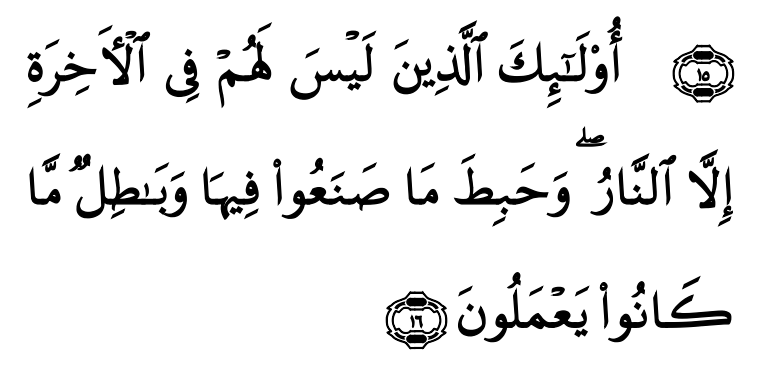

"Barang siapa yang menghendaki kehidupan dunia dan perhiasannya, niscaya Kami berikan kepada mereka balasan pekerjaan mereka di dunia dengan sempurna dan mereka di dunia itu tidak akan dirugikan. Itulah orang-orang yang tidak memperoleh di akhirat, kecuali neraka dan lenyaplah di akhirat itu apa yang telah mereka usahakan di dunia dan sia-sialah apa yang telah mereka kerjakan."

c) QS. Ibrāhim [14 ] : 3

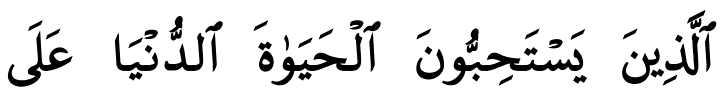

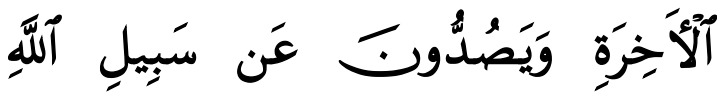

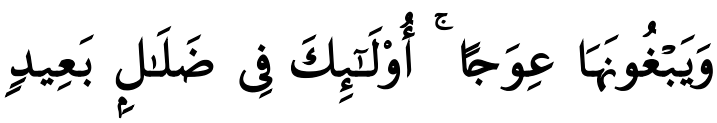

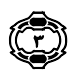

"Orang-orang yang lebih menyukai kehidupan dunia dari pada kehidupan akhirat, dan menghalang-halangi dari jalan Allah dan menginginkan agar jalan Allah itu bengkok. Mereka itu berada dalam kesesatan yang jauh."

d) QS. Al-'Isrā [17]: 18-19

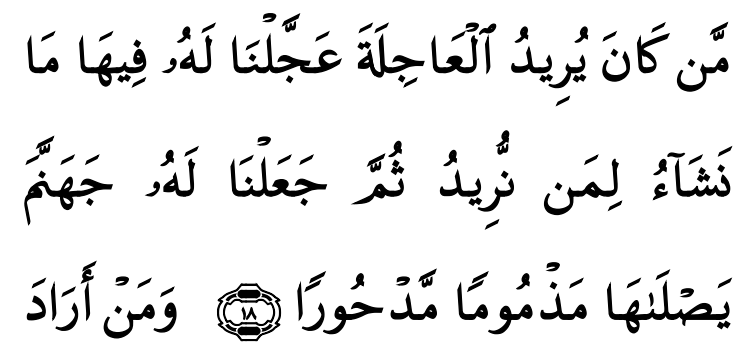

, $260-261$. 
Tika Saripah, Yayan Mulyana dan Undang A. Kamaludin

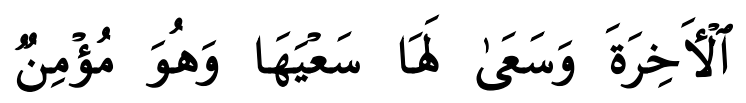

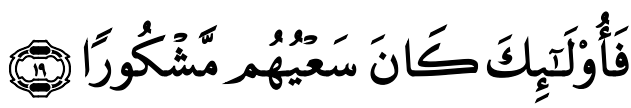

"Barangsiapa menghendaki kehidupan sekarang , maka Kami segerakan baginya di dunia itu apa yang kami kehendaki bagi orang yang kami kehendaki dan Kami tentukan baginya neraka jahannam; ia akan memasukinya dalam keadaan tercela dan terusir. Dan barangsiapa yang menghendaki kehidupan akhirat dan berusaha ke arah itu dengan sungguhsungguh sedang ia adalah mu'min, maka mereka itu adalah orang-orang yang usahanya dibalasi dengan baik."

e) QS. Al-Shūra [42]:20

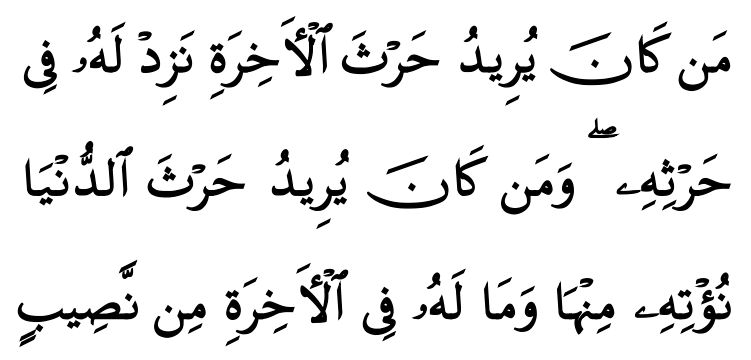

"Barang siapa yang menghendaki keuntungan di akhirat akan Kami tambah keuntungan itu baginya dan barang siapa yang menghendaki keuntungan di dunia Kami berikan kepadanya sebagian dari keuntungan dunia dan tidak ada baginya suatu bahagianpun di akhirat."

f) QS.Al-A'lā [87]:16-17

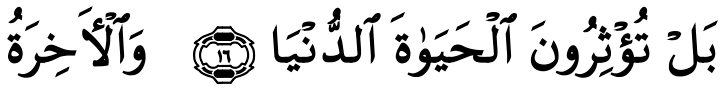

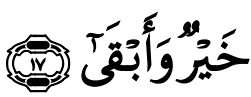

"Tetapi kamu (orang-orang kafir) memilih kehidupan duniawi. Sedang
Fungsi Zuhud Terhadap Ketenangan Jiwa

(Studi Analisis terhadap Tafsir Jailani Karya Abd al-

Qadir Jailāni)

kehidupan akhirat adalah lebih baik dan lebih kekal."

Adapun kategorisasi yang terakhir yakni kerugian manusia yang lebih memilih dunia daripada akhirat. Pada sub bab ini terdapat beberapa ayat yang memiliki orientasi sama, yakni memberitahukan pada penduduk dunia bahwa orang yang lebih cenderung pada kehidupan dunia dan melupakan akhirat mereka hanya akan mendapatkan kehinaan dan kerugian.

Namun seperti halya sebelumnya ayat ayat ini memiliki perbedaan pada setiap pembahasannya.Diantaranya dalam QS. AlA'rāf [07] : 176 dijelaskan bahwa orang yang lebih mencintai pada dunia dan bergantung padanya itu sangat hina dan rendah, mereka senantiasa mengikuti hawa nafsunya, ia ibarat anjing yang apabila di larang keinginannya ia akan menjulurkan lidahnya. Padahal Allah menunjukan padanya melalui ayat-ayat-Nya untuk hidup dengan derajat yang tinggi yakni untuk berpikir dan memahami betapa hinanya dunia ini, tapi mereka malah mendustakan ayat-ayat tersebut. $^{24}$

Sedangkan dalam QS. Hūd [11]: 15-16 dijelaskan bahwa orang yang menginginkan kehidupan dunia dan perhiasannya berupa harta dan anak-anak, maka mereka hanya akan mendapat kenikamatan itu di dunia saja, mereka akan mati dalam keadaan buruk sedangkan di akhirat mereka tidak akan memperoleh apapun kecuali neraka, dan siasialah semua amalan yang mereka kerjakan di dunia. $^{25}$

Adapun dalam QS. Ibrāhim [14 ] : 3 mufasir memaparkan bahwa orang yang lebih menyukai kehidupan dunia yang hanya pinjaman dan akan rusak, daripada akhirat yang memiliki kekekalan dan tidak terikat waktu, serta orang yang menghalang-halangi manusia menuju jalan Allah dan menginginkan agar jalan Allah itu bengkok,

${ }^{24}$ Abd al-Qadir Jailāni, Tafsìr al-Jailāni, Jilid.2 ,137-138.

${ }^{25}$ Abd al-Qadir Jailāni, Tafsìr al-Jailāni, Jilid.2 ,296-297. 
Tika Saripah, Yayan Mulyana dan Undang A. Kamaludin

mereka itu merupakan orang yang berada dalam kesesatan yang jauh dari petunjuk Allah. $^{26}$

Sedang dalam QS. Al-'Isrā [18]: 18-19 di katakan bahwa orang-orang yang menghendaki kenikmatan dunia hal itu kan disegerakan bagi mereka. Padahal pada dunia itu terdapat kepalsuan, penipuan dan bencana yang besar yang bersembunyi dibaliknya.Dan bagi mereka telah disediakan neraka jahanam.Yakni tempat yang diasingkan, mereka memasukinya dalam keadaan tercela dan terusir. ${ }^{27}$

Mufasir menerangkan dalam QS. AlShüra [42]:20 tentang akibat yang didapat dari orang yang lebih menghendaki kehidupan akhirat dan orang yang lebih menghendaki kehidupan dunia. Yakni orang yang menghendaki kehidupan akhirat, keuntungannya akan dilipatgandakan serta mendapat kelezatan ruhani dari Allah dalam ketenangan yang abadi. Dan bagi orang yag lebih menginginkan kehidupan dunia, Allah memberikannya keuntungan yang besar ketika di dunia namun ketika diakhirat mereka tidak akan mendapat keuntungan apapun karena bagiannya sudah habis. ${ }^{28}$

Pada ayat yang terakhir yakni QS. Al-A'lā [87]:16-17 diterangkan tentang orang kafir yang lebih mengutamakan kehidupan dunia daripada kehidupan akhirat yang merupakan kehidupan yang kekal tiada batas. mereka itu termasuk orang-orang yang bodoh yang linglung dan tersesat karena dunia itu bukanlah kehidupan yang sebenarnya, sebagaimana dijelaskan dalam ayat-ayat sebelumnya bhawa dunia hanyalah pinjaman dan semuanya akan binasa, hingga akhirnya mereka tidak memiliki perbekalan apapun untuk kehidupannya di akhirat. ${ }^{29}$ Demikian besarnya kerugian yang di dapat oleh

26 Abd al-Qadir Jailāni, Tafsìir al-Jailāni, Jilid.2 ,408-408.

${ }^{27}$ Abd al-Qadir Jailāni, Tafsìr al-Jailāni, Jilid.3 , 11 .

${ }^{28}$ Abd al-Qadir Jailāni, Tafsìr al-Jailāni, Jilid.3 , 376.

29 Abd al-Qadir Jailāni, Tafsīr al-Jailāni, Jilid.5 410-411.
Fungsi Zuhud Terhadap Ketenangan Jiwa

(Studi Analisis terhadap Tafsir Jailani Karya Abd alQadir Jailāni)

seseorang yang mencintai dunia, ia hanya merasakan kenikmatan yang sesaat. Maka dari itu kita harus lebih bijak dan pandai dalam menjalani kehidupan yang sementara ini

\section{Analisis Kaitan Zuhud dengan Ketenangan Jiwa dalam Tafsir Jailani}

Kehidupan dunia memiliki berjuta pesona secara kasat mata manusia biasa, namun semua hanyalah khayalan bagi orang yang memiliki ketauhidan yang benar, dan mereka memilih untuk berzuhud. Karenanya mereka yang memiliki keimanan yang mantap memilih untuk tidak menyukainya, dan lebih condong kepada akhirat.Sebab mereka memahami betul hakikat dari dunia itu sendiri, selain menipu dunia juga hanyalah kesenangan yang sementara.

Mereka yang berzuhud senantiasa hidup dalam kesederhanaan, baik sederhana secara lahir maupun batin. Secara lahir gaya hidupnya tidaklah berlebih-lebihan, karena mereka tahu ahwa Allah tidak menyukai hal yang berlebih-lebihan. Begitu pula batinnya, pemikirannya tidak ribet, mereka selalu ridho atas nikmat yang diberikan padanya, sedikit maupun banyak.

Berbeda halnya dengan orang yang tergiur oleh kenikmatan dunia, ia akan menjadi budak nafsu karena dunia selalu menuntutnya untuk memenuhi keinginannya. Maka pada akhirnya jika cinta itu telah mengakar, hati akan meminta balasan pada yang dicintainya, yakni dunia itu sendiri. sehingga apabila tidak tercapai keinginannya teradap dunia akan timbul rasa kecewa, bingung dan stress dalam dirinya, dimana semua itu termasuk gangguan kejiwaan yang membuat jiwa seseorang tidak tenang.Ketika jiwa tidak tenang ia akan menimbulkan berbagai masalah baik diri sendiri maupun orang lain.

Jiwa yang tenang merupakan keadaan tertinggi dari perkembangan spiritual.Jiwa yang tenang berada dalam keadaan harmonis, bahagia, nyaman dan damai. Jiwa ini berada dalam keadaan tenang karena mengetahui, walaupun terdapat kegagalan duniawi, hal ini akan kembali kepada Allah. Jiwa ini melakukan penyucian diri terhadap tekanan- 
Tika Saripah, Yayan Mulyana dan Undang A. Kamaludin

tekanan, yang muncul dari pertarungan terhadap kendala yang menghalangi pikiran dan perasaan (Bastaman, 2008: 59).

Jiwa yang tenang dimiliki oleh orang yang beriman dengan ketauhidan yang benar, sehingga ia selalu beramal dengan ikhlas dan senantiasa ridho terhadap takdir yang ditetapkan Allah untuknya. Sebagaiman telah dijelaskan bahwa factor internal adanya ketenagan jiwa itu jika kalbu merasa yakin dengan penuh kemantapan akan kebesaran Allah sehingga ia mampu memberikan garansi ketenangan dan keimanan.seperti kemantapan imannya nabi Ibrahim pada Allah dalam QS. Al-Baqarah [02]: 260

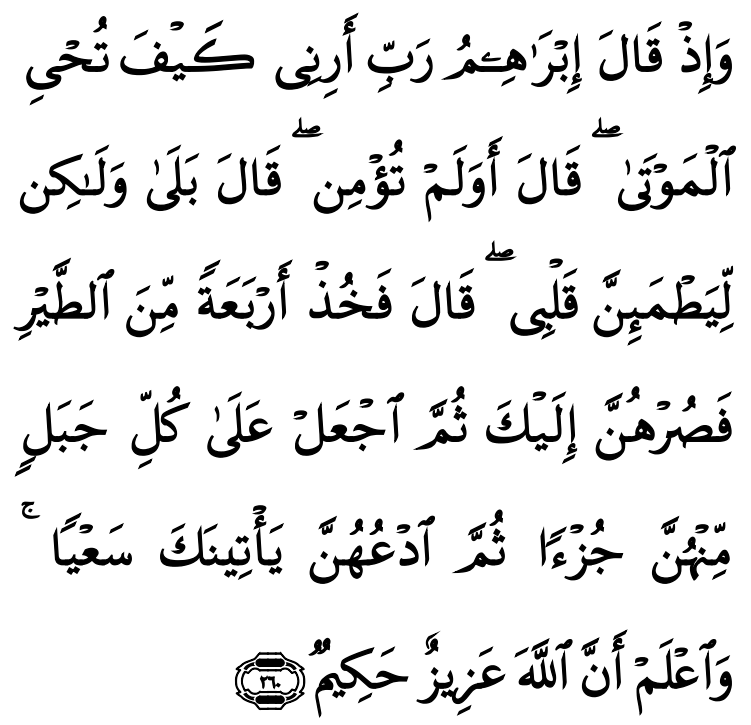

"Dan ketika Ibrahim berkata: "Ya Tuhanku, perlihatkanlah kepadaku bagaimana Engkau menghidupkan orangorang mati." Allah berfirman: "Belum yakinkah kamu?" Ibrahim menjawab: "Aku telah meyakinkannya, akan tetapi agar hatiku tetap mantap Allah berfirman: " ambillah empat ekor burung, lalu cincanglah semuanya olehmu. : "Lalu letakkan diatas tiap-tiap satu bukit satu bagian dari bagian-bagian itu, kemudian panggillah mereka, niscaya mereka datang kepadamu dengan segera." Dan ketahuilah bahwa Allah Maha Perkasa lagi Maha Bijaksana."
Fungsi Zuhud Terhadap Ketenangan Jiwa (Studi Analisis terhadap Tafsir Jailani Karya Abd al-

Qadir Jailāni)

Mufasir menjelaskan bahwa ayat ini mengisahkan Nabi Ibrahim as.yang menjadi kekasih Allah mendapat ujian yang dahsyat secara dzohir dan batin. Adapun ujian yang menimpa batinnya yakni berupa kekacauan dalam pemahaman rububiah.Pada awalnya beliau ingin menambah kuat keyakinannya dengan melihat secara kasat mata tentang kekuasaan-Nya. Maka untuk meyakinkannya Allah memerintahkannya mencincang 4 jenis unggas yakni merak, gagak, ayam jantan dan merpati, dan menyimpan semua bagiannya secara terpisah di setiap gunung yang ia ketahui. Lalu memanggil mereka secara bersamaan, mereka pun datang dalam keadaan kembali utuh dengan cepat. Adapun maksud dari permintaan Nabi Ibrahim tersebut yakni untuk menambah kemarifatan serta melawan dan mengeluarkan tipu daya yang menghampiri batinnya dari lemahnya ubudiyyah dan sifat ketuhanan, selain itu karena kerinduannya yang sangat terhadap dzat yang dicintainya, yaitu Allah SWT. Hingga setelah menyaksikan hal tersebut merasa tenanglah jiwanya dan semakin mantap keimanannya. ${ }^{30}$ Begitu pula orang yang berzuhud, mereka memiliki ketenangan jiwa dan keyakinan yang mantap terhadap janji Allah yang ada dalam al - Quran bahwa akhirat itu lebih baik dan lebih kekal, sehingga mereka lebih mengutamakan akhirat.

Jiwa yang tenang akan tumbuh karena kemampuannya untuk menempatkan sesuatu sesuai tempatnya yang didasari keimanan. Dengan dasar iman, manusia akan menerima segala sesuatu yang dihadapinya, baik senang, susah, menang dan kalah ia mejalaninya dengan rida. Jika ia mendapat nikmat dan kesuksesan, ia tidak akan melonjak kegirangan. Sebaliknya, jika ia mengalami bencana dan kekalahan, ia tidak berduka cita dan putus asa. ${ }^{31}$ Sehingga seseorang mencapai ketenangan jiwa seperti yang dalam QS. Al Fajr [89]:27-30

${ }^{30}$ Abd al-Qadir Jailāni, Tafsìr al-Jailāni, Jilid. 1 hlm 238 .

31 'Arifatul Hikmah, Skripsi Jiwa yang Tenang dalam al Quran, UIN Sunan Kalijaga, 2009, 73. 
Tika Saripah, Yayan Mulyana dan Undang A. Kamaludin

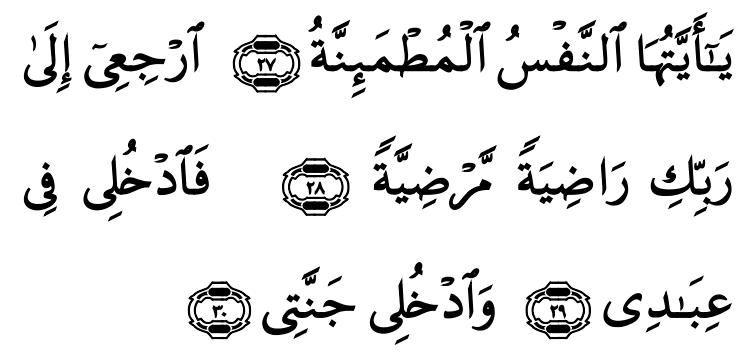

"Hai jiwa yang tenang . Kembalilah kepada Tuhanmu dengan hati yang puas lagi diridhai-Nya, Maka masuklah ke dalam jama'ah hamba-hamba-Ku, masuklah ke dalam syurga-Ku."

Abd Al-Qadir Jailānidalam penafsirannya menyebutkan bahwa orang yang jiwanya tenang itu orang yang senantiasa berbekal di dunianya untuk kehidupan akhirat dengan ketakwaan serta senantiasa menjauhkan diri dari maksiat. Ia senantiasa ridho dengan ketetapan Allah baik senang maupun susah hatinya tidaklah terguncang karena mereka tidak memperdulikan kehidupan dunia yang meliputi kekuasaan dan kemewahannya. Sehingga di akhirat ia akan di masukan ke dalam surga. ${ }^{32}$ Berdasarkan pemaparan dalam penafsiran ayat ini sangat jelas bahwa orang yang memiliki jiwa yang tenang ialah orang memiliki karakter zuhud terhadap dunia.Selain itu masih banyak ayat lain yang menyatakan hal tersebut seperti penafsirannya dalam QS. Al Kahfi[18]: 45-46, QS.Ar Ra'd [13]:26-28, QS. Al Hadid [58]: 20, dll.

Orang yang memiliki sikap zuhud dapat menimbulkan ketenangan jiwa pada seseorang. Karena mereka senantiasa menerima terhadap nikmat yang dikaruniakan padanya, baik banyak maupun sedikit itu tidak akan membuat jiwanya susah. Mereka akan tetap tenang sesulit apapun keadaannya karena dalam hatinya tidak ada sama sekali kecintaan terhadap dunia tersebut.Mereka yang berzuhud di dunia mendapat ketenangan saat menghadapi segala kesusahan, di akhirat mendapat pahala Allah dan kenikmatan yang kekal berupa surga-Nya Allah.

\footnotetext{
32 Abd al-Qadir Jailāni, Tafsìr al-Jailāni, Jilid.5
}

Fungsi Zuhud Terhadap Ketenangan Jiwa (Studi Analisis terhadap Tafsir Jailani Karya Abd alQadir Jailāni)

\section{SIMPULAN}

Berdasarkan penelitian dapat disimpulkan bahwa zuhud menurut Abd Al-Qadir Jailāniyakni prilaku hidup orang - orang yang pandai dalam meneliti dan memahami kehidupan dunia sehingga mereka mengetahui bahwa dunia ini tidaklah kekal dan hina karena semua itu hanya sementara dan kepalsuan belaka. Karenanya mereka akan memilih mengutamakan kehidupan akhirat yang kekal dan senantiasa menjalankan amalamal saleh yang dapat mendekatkan hamba kepada Allah sehingga meraih martabat tinggi dan selamat dari siksa, serta mendapatkan kelezatan ruhani berupa ketenangan jiwa.

Adapun kategorisasi dari ayat - ayat tentang zuhud antara lain :

1. Permisalan dunia yang terdapat pada ayat QS. Yūnus [10]: 24 dan QS. Al Kahfi[18]: 45-46. Keduanya mengatakan bahwa perumpamaan dunia yang diibaratkan sebagai air yang turun dari langit yang memiliki tingkah yang menipu. Karena dalam sekejap dapat menghancurkan indahnya tanaman dirawat manusia. Begitu pula kehidupan dunia, sifatnya hanyalah sementara, anak, keluarga dan harta yang dimiliki, semuanya milik Allah dan berada dalam kekuasaan-Nya.

2. Sifat dan hakikat dunia dalam Alquran

a. Kehidupan yang sementara dan kesenangan yang menipu yang terdapat dalam QS. 'Ali 'Imrān [03]: 185, QS. AlA'rāf [07]: 51, QS. Al- Ra'd [13]:26 dan QS. Luqmān [31] : 33. Yang semuanya menerangkan bahwa dunia itu hanyalah kehidupan yang sementara, namun kebanyakan mereka terpedaya oleh kenikmatanya, sehingga melupakan akhirat.

b. Permainan yang melalaikan, yang diterangakan dalam QS. Al-'Ankabüt [29]: 64 dan QS. Al Hadid [57]: 20 bahwa dunia itu merupakan permainan melalaikan dimana perhiasan dan kenikmatannya fana dan tidak tetap perputaran yang ada padanya tidak hakiki ,423. 
Tika Saripah, Yayan Mulyana dan Undang A.

Kamaludin

semuanya hanyalah fatamorgana. Dan di akhirat itu memiliki kenikmata hakiki dan kelezatan ruhani yang tinggi. Perhiasan dunia itu hanyalah permainan yang dihiasi dengan kebatilan

c. Cobaan, salah satunya dalam QS.AlTaghabūn [64]: 15, menyatakan bahwa kehidupan dunia yang berupa anak dan harta adalah cobaan yang besar. Karenanya jangan sampai tertipu olehnya, hanya karena terlalu mencintainya hingga melupakan Allah.

d. Sengaja dijadikan indah untuk kesenangan, yakni dalam QS. Al-Baqarah [02]: 212 dan QS. 'ATi 'Imrān [03]: 1, yang memberitahukan bahwa dunia yang samar itu sengaja dijadikan terlihat indah dalam pandangan manusia supaya menjadi kencintaan dalam hatinya sehingga mereka menyombongkan diri dengan yang berada padanya.

3. Kerugian memilih dunia yang diterangkan dalam QS. Al-A'rāf [07] : 176, QS. Hūd [11]: 15-16, QS. Ibrāhim [14 ] : 3, QS. Al-'Isrāa [18]: 18-19, QS. Al-Shūra [42]:20, dan QS.Al-A'lā [87]:16-17, mereka hanya akan mendapatkan kehinaan dan kerugian.

Kaitan zuhud sendiri terhadap ketenangan jiwa yakni prilaku hidup zuhud tersebut dapat memberikan efek ketenagan dalam jiwa seseorang. Karena orang yang berzuhud itu senantiasa menerima terhadap nikmat yang dikaruniakan padanya, baik itu banyak maupun sedikit, hal itu tidak akan membuat jiwanya susah. Mereka akan tetap tenang sesulit apapun keadaannya karena dalam hatinya tidak ada sama sekali kecintaan terhadap dunia.
Fungsi Zuhud Terhadap Ketenangan Jiwa

(Studi Analisis terhadap Tafsir Jailani Karya Abd al-

Qadir Jailāni)

\section{DAFTAR PUSTAKA}

Hajjaj, Bin Muslim. Șahih Muslim. Beirut : Dar Ihya Turath, t.t

Hanani, Dinar Gusti dan Muhammad Syafiq, Jurnal Penelitian Psikologi "Mengatasi Ancaman Identitas Kemiskinan: Studi Kasus Sebuah Keluarga Miskin Di Surabaya”, 2013, Vol. 04, No. 02, 120141.

Hikmah, 'Arifatul. Jiwa yang Tenang dalam Alquran, dalam Skripsi UIN Sunan Kalijaga, 2009.

Jailāni, Abd al-Qadir Raihlah Hakikat Jangan Abaikan Syari'at, (terjemahan Adab al Suluk wa al Tawasul ila Manazil al Muluk). cet.V .Pustaka Hidayah: Bandung, 2013.

Jailāni, Abd al-Qadir. Tafsìr al Jailāni. Jilid.1 . Pakistan: Maktabah Ma'rufiyyah,t.t.

Jailāni, Abd al-Qadir. Tafsìr al Jailāni. Jilid.2 . Pakistan: Maktabah Ma'rufiyyah,t.t.

Jailāni, Abd al-Qadir. Tafsìr al Jailāni. Jilid.3 . Pakistan: Maktabah Ma'rufiyyah,t.t.

Jailāni, Abd al-Qadir. Tafsìr al Jailāni. Jilid.4 . Pakistan: Maktabah Ma'rufiyyah,t.t.

Jailāni, Abd al-Qadir. Tafsir al Jailāni. Jilid.5 . Pakistan: Maktabah Ma'rufiyyah,t.t.

Muhammad Bin Abdullah, Hakim. Mustadrak al-Hakim. Dar al-Kitab al-'Ilmiyyah, 1990

Najar, Amir 'an . Ilmu Jiwa dalam Tasawuf Studi komparatif dengan Ilmu Jiwa Kontemporer. Jakarta: Pustaka Azzam,2001.

Tirmidzi, Muhammad bin Isa. Sunān Tirmidzi. Mesir: Sharikah al-Maktabah, 1975M. 